\author{
Article published in Accounting, Auditing \& Accountability Journal \\ Vol. 30 No. 7, 2017 \\ pp. 1511-1536
}

\title{
A Blueprint towards Accounting for the Management of Ecosystems
}

\author{
Clément Feger and Laurent Mermet \\ AgroParisTech and Centre for Ecology and Conservation Sciences (CESCO), \\ National Museum of Natural History, Paris, France
}

\begin{abstract}
Purpose - This paper proposes a new ecological-issues-centered accounting research agenda, at the crossroads of accounting research and conservation science.

Design/methodology/approach - Based on a case study of the Natural Capital Project, the research examines the efforts and challenges of conservation practitioners regarding the use of evaluative information systems for conservation (EISC) in complex social and ecological contexts. It discusses why and how, to address these challenges, EISC promoters would benefit from theoretical and empirical insights coming from accounting research.

Findings - The paper suggests that the use of new information systems centered on organized collective action for biodiversity conservation should be regarded as a new type of accounting for the management of ecosystems, complementary to organization-centered biodiversity accounting and to ecosystem accounting at the national scale. A research agenda inspired by critical accounting should be developed for EISC design and use by: (1) critically analyzing the organizational models currently underlying the use of new calculative practices for ecosystems; (2) developing new analytical and practical avenues on the basis of more explicit and powerful theories adapted to collective action for conservation perimeters.

Originality/value - The paper shows the importance of combining three domains of research and practice that are usually disconnected: (1) the design and use of innovative information systems in biodiversity conservation research and practice; (2) accounting research; (3) theories and conceptual models of collective action to resolve ecological challenges.
\end{abstract}

Keywords: ecological accounting, accountability, biodiversity conservation, ecosystem services, accounting entity

Paper Type: Conceptual paper 


\section{Introduction}

\subsection{Biodiversity as a new territory for organization-centered social and environmental accounting}

From the 1970s onward, part of accounting research has embarked on a risky but visionary journey by turning its eyes to environmental issues (Richard, 2012). Since then, social and environmental accounting (SEA) research has steadily increased in popularity (Cullen and Whelan, 2006; Eugénio et al., 2010; Gray, 2007; Mathews, 1997, 2000; Owen, 2008; Parker, 2005, 2011; Richard, 2012; Spence et al., 2010). This trend has been consistent with the growing importance of environmental concerns and the sustainable development agenda in society over this period. It reflects the many efforts by SEA researchers and practitioners to broaden accounting's scope and make organizations and business more accountable for their impact on society and the natural environment (Gray, 2008, 2010; Gray, Adams, et al., 2014; Gray et al., 1995). A wide range of environmental issues has so far been explored by SEA (pollution, water quality, deforestation, climate change, etc.). It is only recently though that accounting research has started to pay greater attention to biodiversity and ecosystem conservation (Jones, 2014a, 2014b; Jones and Solomon, 2013; see also the 2013 AAAJ special issue on the topic vol.26:5), with the hope that "by accounting for biodiversity impacts, by reporting on actions taken to enhance and protect biodiversity, organizations themselves will be spurred on to take further and more effective action to conserve, preserve and enhance the variety of species on Planet Earth" (Jones and Solomon, 2013, p. 670).

Accounting for biodiversity research at the organizational scale today includes essentially: (1) original propositions for extra-financial biodiversity reporting (GRI, 2011; Jones, 2014c, 1996, 2003; Thomson, 2014) as well as critical studies of firms' current biodiversity reporting and corporate disclosure practices (Atkins et al., 2014; Van Liempd and Busch, 2013; Rimmel and Jonäll, 2013); (2) propositions to integrate biodiversity, ecosystem services and natural capital information in organizations' management and financial accounting systems (Houdet, 2010, 2012; Houdet and Germaneau, 2014; Ionescu, 2016; Rambaud and Richard, 2015); (3) full cost accounting methods to measure the hidden costs of organizations' impacts on the degradation of ecosystems (Davies, 2014; Kering, 2015; PUMA, 2010; TEEB, 2012a); (4) the development of new ad-hoc valuation and decision-making tools to help organizations assess their interdependencies with ecological systems and the associated risks for their operations and supply chains (Hanson et al., 2011; Havas et al., 2014; NCC, 2016; Waage and Kester, 2015; Zhang et al., 2010a, 2010b).

While these various approaches differ from one another on multiple dimensions (i.e. purpose and intended users, biodiversity Vs ecosystem services; monetary metrics Vs biophysical metrics; integration in existing accounting systems Vs new decision-making tools, etc.), they all have in common to consider existing formal organizations and business as the central 'accounting entities', i.e. "the objects and activities of which the reports [will] speak" (Kurunmaki, 1999, p. 219). Seen from such a perspective, biodiversity conservation is essentially conceived as a problem that must be addressed by extending organizations' conventional accounting perimeters to gradually integrate new biodiversity-related 
information. This would enhance the capacity of organizations to individually take into account and manage their relations with ecological systems, and it would foster their public accountability on their degradation.

\subsection{Ecosystem accounting innovations to measure natural capital at the national scale}

On the other side of the accounting for biodiversity spectrum and at the crossroads of national accounting, economics, statistics and ecological science, some efforts are made since the 1980s to account for the health of ecological systems at the national, supra-national or regional scale (Bouni, 1996; Boyd and Banzhaf, 2007; Edens and Hein, 2013; Hein et al., 2015; Mäler et al., 2008; Sukhdev and Feger, 2012; TEEB, 2010; Weber, 2014a). While the definition, scope, metrics, quantification conventions and scientific methods of so-called "ecosystem accounting" approaches are still widely debated (Edens and Hein, 2013, pp. 4344), their overall aim is to "monitor changes in ecosystem conditions and ecosystem services over time from a spatial perspective in a way that is persistent with national accounting" (Schröter et al., 2014, p. 540). This innovation agenda is aligned with current international political incentives such as the Strategic Plan for Biodiversity 2011-2020 adopted in Nagoya in 2010 that sets the objective "to integrate biodiversity values" into national development plans and into national accounting and reporting systems (Weber, 2014a, p. 9). It was recently enhanced by the adoption in 2012 of the new version of the System of EnvironmentalEconomic Accounts "Central Framework" by the United Nation's Statistic Commission (UN, 2014) and its complementary volume specifically dedicated to the experimentation of ecosystem accounting ("Experimental Ecosystem Accounting" - SEEA-EEA), that seek to go beyond simple natural resources accounting approaches (EC, 2013).

As an illustration of the field's current diversity, contributions include: (1) the Wealth Assessment and Ecosystem Valuation of Ecosystem Services (WAVES) program hosted by the World Bank since 2010, that develops monetary valuation approaches of ecosystem services and supports pilot projects in multiple countries (WAVES, 2014); (2) the Ecosystem-Capital Accounts developed by the European Environmental Agency at the European scale that privileges biophysical accounts and land use data (Weber, 2011, 2007); (3) the articulation of mixed valuation methodologies into an original accounting model proposed by the Convention Biological Diversity (Weber, 2014a); (4) the Joint Perspective Model developed by the Australian Bureau of Meteorology that introduces a muti-perspective accounting approach (economic, human an cultural, physical and biological, etc.) (BoM, 2013). Other propositions related to this field have been developed by public agencies, individual research teams, or environmental think tanks and focus on specific countries, regions, ecological compartments or economic sectors (Borucke et al., 2013; Campbell and Tilley, 2014; Eurostat, 2002; Gundimeda et al., 2007; Remme et al., 2014; Weber, 2014b; Zhang et al., 2007).

Despite this variety, all national ecosystem accounting approaches essentially share the ambition to introduce standard methods to aggregate spatial, biophysical and economic information on ecological systems and their interaction with human activities. They produce totalizing figures, or what we could refer to as 'macro-ecological balance-sheets', of the health, stocks, flows and value of natural capital over time. Their common feature is thus to 
consider states and other already constituted political, territorial and socio-economic entities as the main users of such accounting information, and to regard their spatial boundaries as the relevant accounting for biodiversity perimeters. Seen from this perspective, biodiversity conservation is essentially a matter of extending and/or complementing states' conventional national accounting systems in order to ultimately adjust or redirect public authorities' agency and their economic and regulatory instruments in favor of a better governance of natural capital.

\subsection{Accounting for the management of ecosystems: contributing to an emerging third front in accounting for biodiversity research}

Hence, most of accounting for biodiversity research today is centered on already existing accounting entities, either organizational or national. However, none of these two kinds of accounting perimeters are by themselves fit to effectively address conservation issues and operationalize the collective management of ecological systems. On one side, continuing improvement of the accounting of organizations, in particular of business, is a necessary but not a sufficient condition for the long-term protection of the biosphere. Most ecological systems are such that their conservation, restoration or sustainable management depends on more than just one organization. As a result, even an ambitious and relevant SEA scheme for a company can rarely suffice to inform and organize our collective accountability for a given ecological system. On the other side, we are indeed in great need of complex information systems able to produce macro-representations and to account for the status, use and cumulated degradation of ecological systems over time on a given spatially defined entity including at the planetary scale. However, this will remain a vain effort that cannot "support the generalization of ecological management" as Weber (2014a, p. 18) hopes it would, if it is not met with the ability to assign responsibilities and hold organizations and economic sectors accountable for their specific (positive or negative) roles in ecological degradations at a more disaggregated level.

The challenges of articulating organizational entities' ecological performances accounts developed at the micro level with accounts of the sustainability of Earth's life support system at a macro scale have been debated in previous SEA works, through the critique of prevalent corporate sustainability reporting and management accounting frameworks and practices and through the proposition of new approaches to organizations' environmental accounts development (Gray, 1992; Milne, 2007, 1991, 1996; Milne et al., 2009; Milne and Gray, 2013). To make substantial progress towards such an articulation, we believe that in addition to efforts to integrate biodiversity in business accounting systems and to the extension of national accounting systems to natural capital, another layer of stand-alone accounting innovation is needed, centered on accounting entities that correspond to the organized management of specific ecosystems or ecological issues (Feger, 2016).

Part of SEA research has already started to point to the "challenge offered by the possibilities of wider entity accounts" and to explore new ways of creating change beyond direct action on organizations and business, and through the study and design of "new accounts" (Gray, Brennan, et al., 2014). This orientation appears as particularly relevant for an emerging strand of accounting for biodiversity research where new accounting entities composed of one or more organizations - are increasingly being conceptualized and studied: a national government responsible for the management of mangroves (Siddiqui, 2013); regional public authorities in charge of local habitats and fauna (Raar, 2014); forest certification 
schemes (Borsato et al., 2014; Elad, 2014) and biodiversity offsets mechanisms (Cuckston, 2013; Tregidga, 2013); a governance and funding program for forest management (Khan, 2014); a unsustainably managed water catchment and a group of irrigators (Saravanamuthu and Lehman, 2013). The work of Dey and Russell (2014, p. 249) on the management of river Garry is particularly illustrative of this shift towards "a more system-level conceptualisation of the accounting entities". The authors focus on a perimeter comprised of a river, its surrounding catchments and the organizations that operate and/or impact them. They extend the scope and reformulate the question of accountability, not limited to business accountability, but rather gradually understood as the various relationships and dynamics by which people and multiple organizations give, receive, demand and exchange various forms of accounts (rule-enforcing compliance accounts, corporate disclosure accounts, 'external accounts') related to a given ecological issue.

A small part of accounting for biodiversity studies is thus somehow already leading the way towards a further extension of the SEA's research agenda, beyond its business and organization-centered dominant focus. Encouraged by these researches, this paper seeks to contribute to ecological-issues-centered or ecological-system-centered accounting, by proposing the more systematic development of what we refer to as 'Accounting for the management of ecosystems' (AfME), where accounting frameworks and methods are centered not on given organizations or nations, but on given ecological issues and their effective long-term collective management. Ultimately, we believe that such accounting systems could play a role that neither organization-centered accounting nor national natural capital accounting can play, i.e. gradually equip emerging systems of accountabilities between organizations that share the responsibility for managing specific ecosystems or ecological issues.

In the following sections, the paper will cover what we consider to be the main steps for further development of such ecosystem-issue-centered accounting systems: (1) centering part of accounting research on the emerging perimeters of organized action for ecological systems conservation and on innovative information systems developed by conservation practitioners; (2) establishing new collaborations between accounting researchers and evaluative information systems designers and users in the field of conservation; (3) recognizing the profound similarities between issues raised by the design and use of such evaluative information systems and issues raised by the design and use of accounting systems in the context of the management of firms and organizations, which will we do here based on a specific case example; (4) pointing at specific challenges and areas of collaboration where evaluative information systems designers in the field of conservation could benefit from knowledge and experience accumulated by critical and SEA accounting research and debates; (5) studying, criticizing and enriching the connections between the design and use of evaluative information systems for conservation with theoretical frameworks specifically well-adapted to study the institutional, political and organizational dimensions of organized action for biodiversity in emerging perimeters.

\section{Centring accounting on organized action for ecological systems conservation}

Ecological system conservation issues are generally characterized by the interplay of multiple managers and stakeholders who, intentionally or not, have positive or negative effects on the natural environment and act in a fragmented, divisive, competitive and often 
adversarial way. The absence of an organizational "centre" or of what could be referred to as a "unity of agency" (Mermet et al., 2013) requires that we focus on the very serious agency problems that underlie most ecological issues - who has the capacity to act, with whom and in what form of coordination, on what object and in what perimeter, what activities does that entail? Therefore, from the perspective of conservation scientists and practitioners, acting for biodiversity conservation and more generally for a sound management of ecological systems is not so much a matter of conducting change in well-bounded and formally constituted organizations. It consists rather in designing, implementing and managing various forms of collective organized action about specific ecological issues. As we use the expression "organized action", we refer to Crozier and Friedberg's definition as "the process through which the strategic interactions among a set of actors placed in a given field of action and mutually dependent for the solution of some common 'problem' are stabilized and structured" (Crozier and Friedberg, 1995, p. 75). In the broadest possible terms, the question we are addressing in this paper can be expressed this way: what accounting approaches should equip organized collective action to sustainably manage ecosystems?

The question does not point to a lack of initiatives dealing with ecosystem management issues: there exists a significant body of literature in social sciences or using interdisciplinary approaches to understand the challenges of collective action for conservation (Callicott et al., 1999; Kareiva and Marvier, 2012; Mascia et al., 2003; Mermet et al., 2013; Scoones, 1999; Soulé, 1985). Neither does the question refer to a lack of efforts to develop ambitious evaluative information systems for conservation (EISC). Quite the contrary, in their efforts to tackle the challenges associated with the task of guiding action for biodiversity conservation, researchers and field practitioners have been developing and mobilizing an increasing number of new calculative practices to explore, assess and monitor multiple aspects of ecological systems. To mention just a few examples, ecological indicators informing on the level of fish stocks or the quality of a forest cover (Heink and Kowarik, 2010); performance metrics to measure the costs of ecosystem restoration and maintenance (Vaissière et al., 2013); Red Lists of threatened species useful to establish conservation priorities (Young et al., 2014); biophysical assessments and economic valuations of the benefits of ecosystems to human well-being (ecosystem services) (Kareiva et al., 2011; MEA, 2005). Overall, innumerable EISC centered on ecological entities (a bird population, an ecological corridor, a system of wetlands, etc.) are being developed for conservation action. However, they have only mixed results to show as they raise a whole set of difficulties hindering their implementation or limiting their effectiveness (Dale and Beyeler, 2001; Jørgensen et al., 2013; Müller and Burkhard, 2012; Niemeijer and de Groot, 2008; Rametsteiner et al., 2011; Rapport and Hildén, 2013; Turnhout et al., 2007).

To understand and deal with these difficulties, our proposition is to consider evaluative information systems for conservation (EISC) as accounting systems for the management of biodiversity conservation action. As we shall elaborate, our reason for this proposition is twofold. (1) One of the main weaknesses of such information systems is that they often remain disconnected from lasting and effective collective decision and action for ecosystem conservation; we consider one of the fundamental reasons for this is their often embryonic or problematic connection to organized action and to the creation of new effective accountabilities around ecological issues. (2) By contrast, such a connection between information systems, organization, institution and action is the strong point, the raison d'être of accounting research and practice (Chapman et al., 2009b). Therefore, our working hypothesis is that by rethinking evaluative information systems for conservation (EISC) as accounting systems for the management of ecosystems, one may transfer useful conceptual 
and methodological resources from accounting research to the conservation field, and more strongly connect the design and use of EISC with appropriate and explicitly debatable conceptions/theories of organized conservation action.

\section{Establishing new collaborations between accounting research and EISC designers and users}

From the point of view of conservation science, our hypothesis stands in a relative academic vacuum. A recent systematic review of research projects by the French Biodiversity Research Foundation (Chaveriat et al., 2011) shows that collaborations of conservation science with management and organization studies are very limited comparatively to other social science disciplines, and almost entirely absent with accounting as an academic field. There are good reasons behind this limited connection between conservation and accounting. Firstly, they tend to focus on quite separate terrains, and on very different action perspectives (respectively: civil society advocacy and public policy, versus the management of mostly private organizations), so that there has been little incentive to connect. Secondly, direct connection, i.e. applying methods directly from accounting to EISC, or trying to adapt them without deep theoretical reconsideration, is bound to prove disappointing for one fundamental reason: current accounting methods are designed to build information systems for, and fill the organizational needs of, organizations (companies, public administrations) that are deeply different from the organized action systems required to resolve ecological issues and conserve ecosystems. As this gap cannot be bridged directly by simple transfers and adaptation of methods (from accounting to conservation, nor from EISC to conventional accounting), significant new theoretical resources must be introduced to create the new connections we believe are needed, and new collaborations need to be established between accounting researchers and EISC designers and users in the conservation field.

Let us somewhat rephrase the question such resources should help to address: what accounting principles could guide the design and use of EISC in a way that would be relevant for organized action systems capable of adequately tackling conservation issues? The heart of our argument here will be that two bodies of literature and theory should be mobilized and combined to build the required new connections: (1) critical accounting research (others may refer to this stream of research as interdisciplinary, interpretive or alternative accounting research; for further discussion, see for instance Ahrens et al., 2008; Armstrong, 2008; Baxter et al., 2008; Broadbent and Laughlin, 2013; Parker, 2008; Roslender and Dillard, 2003), that has allowed to gradually expand the boundaries of reasoning about accounting systems until it becomes firmly articulated with reasoning about organized action (Chapman et al., 2009a); (2) the set of different but complementary theories that are put forward to account for the challenges and efforts of organized action for biodiversity and their specific accountability issues (and more generally, dealing with the ecological crisis). In brief, the crux of our argument is that combining the knowledge accumulated by decades of critical accounting research (Baxter and Fong Chua, 2003; Chapman et al., 2009a; Naro, 2010) with theoretical resources specifically fit to understand the organizational, institutional and political dimensions of ecological issues, could bring decisive new insights to the conservation community in its efforts to design and use calculative practices for the collective management of ecological systems. Reciprocally, doing so could connect SEA researchers with a clear agenda of work already centered on ecological entities and based on a strong and explicit normative orientation in favor of ecosystem conservation. 
By choosing this path, we are confident that rich cross-fertilizations would arise both for accounting academics and conservation researchers and practitioners. Accounting research could bring decisive contributions to the conservation community in their efforts to better organize the collective management of ecosystems through the development and use of innovative information systems. The current state of the art of EISC still leaves unexplored a plethora of organizational, institutional and political issues related to their design and use. By considering EISC as essentially falling under the realm of Accounting for the management of ecosystems, and while keeping in mind the teachings of critical accounting and SEA, conservation practitioners and accounting researchers can collaborate to investigate, untangle and acquire more leverage to act on these largely unresolved issues.

Conversely, what would such an agenda bring to accounting research? Some authors in SEA research (Allen, 2014; Bebbington and Larrinaga, 2014; Brown and Dillard, 2013; Gray, Brennan, et al., 2014; Spence et al., 2010) as well as in the wider critical accounting research community (Ahrens et al., 2008; Armstrong, 2008; Baxter et al., 2008; Hopwood, 2007; Parker, 2008) have recently been entering a period of self-doubt on the identity and the orientation of their field and have called for the emergence of "something that works" (Quattrone, 2009, p. 622). By establishing strong collaborations with the conservation community, accounting researchers can be sure to find colleagues who are not only interested in deconstructing current practices and information systems, but have in fact a strong desire to analyze, criticize, invent, design and construct new accounting entities and accountability systems. To Chapman et al.'s $(2009 \mathrm{~b}$, p. 21) claim that "accounting is too important to be studied only by accountants!", we will add that evaluative information systems for conservation (EISC) are too serious to be studied only by ecologists and economists, and could greatly benefit from the contributions of accountants!

\section{The Natural Capital Project toolkit: an example of EISC striving to become an operational accounting system adopted by ecosystem managers}

As a case example, we will focus on the EISC developed by the Natural Capital Project (NCP) and specifically designed to be used in a great variety of multi-stakeholders decisionmaking and organized action contexts. These EISC are illustrative of the larger set of socalled ecosystem services assessment tools, which have been promoted in the past ten years by various conservation research organizations (Bagstad et al., 2013; Birch et al., 2014; Kareiva et al., 2011; Peh et al., 2013). The Natural Capital Project (NCP) was formed in 2006 under the premise that better information on biodiversity and ecosystem services can be used to inform decisions and improve both human well-being and ecosystem conditions (Kareiva et al., 2011). Since its creation, the NCP has been working on its main open-source toolbox called "InVEST" (Integrated Valuation of Ecosystem Services and Tradeoffs), as well as on other more specialized tools or complementary modules such as OPAL (Offset Portfolio Analyzer and Locator) or RIOS (Resource Investment Optimization System). Today, InVEST integrates 17 models that analyze different aspects of marine and terrestrial ecosystems. These models use ecological production functions to estimate how the intensity of human activities, climate change and the quality of ecological functioning can change the local provision of ecosystem services (Ibid). It also proposes methods to assess and make visible the various trade-offs and synergies among them (e.g. the trade-off between carbon storage and water quality in forest management) (Chisholm, 2010; Onaindia et al., 2013). InVEST can produce maps, quantitative biophysical outputs and in some cases monetary estimates of the provision 
of multiple ecosystem services on a landscape. In the designers' own words, these evaluative information systems should enable scientists and decision-makers to move "from abstract, conceptual arguments about the importance of ecosystem services to specific quantification of the level, value and spatial distribution of ecosystem service benefits" (McKenzie et al., 2011, p. 339).

One of the core hypotheses of the NCP is that "in principle, putting [ecosystem services] information in the hands of decision-makers should lead to improved landscape planning and management" (Polasky et al., 2011, p. 260) and result in more sound and efficient ecosystem conservation (Daily et al., 2009, 2011; Tallis and Polasky, 2009). Today, "numerous efforts are underway to make the concept of ecosystem services operational and linked to decisionmaking" (Ruckelshaus et al., 2015, p. 11). The InVEST methodology has by now been applied, tested and refined in more than 20 decision contexts around the world including spatial planning, development impacts and permitting, adaptation to climate change, ecological restoration, etc. (Arkema et al., 2013; Bhagabati et al., 2012; Cabral et al., 2016; Feger et al., 2015; Goldstein et al., 2012; Guerry et al., 2012; Nelson et al., 2009; Rosenthal et al., 2014; Ruckelshaus et al., 2015).

To further develop one specific example, we will refer to a recent application of InVEST by the NCP that we briefly describe here. Since 2008 along the West coast of Vancouver Island in British Columbia, diverse stakeholders and decision-makers (federal, provincial and local governments representatives, First Nations groups, fishermen, extractive industries, companies from the tourism sector, etc.) have participated in a marine spatial planning process led by the West Coast Aquatic Management Board (WCA) (Guerry et al., 2012). The initial vision was to ultimately "manage resources for the benefit of current and future generations of people and the natural systems on which they depend" (Ibid, p. 115). This requires to balance and organize a mix of activities and ecosystem uses that are of different values to the different stakeholders (McKenzie et al., 2014). They include "existing extractive, industrial and commercial uses, traditional First Nations subsistence and ceremonial uses, recreation and tourism and emerging ocean uses such as the extraction of wave energy" (Guerry et al, 2012, p. 115). The WCA benefited from the help of NCP scientists whose role was mainly to integrate ecosystem services modelling in the decisionmaking and planning process in order to "(1) assess the suitability of regions for different activities; (2) assess how alternative management plans might affect a range of ecosystem services; and (3) identify the marine-use conflicts likely to arise from alternative spatial plans" (Bernhardt, et al., 2012). The different types of evaluative ecological and economic information produced (vulnerability of the shoreline to erosion and flooding, shellfish aquaculture economic revenues, water quality impacts of touristic float homes, etc.) as well as local and traditional knowledge were used for the development of different planning scenarios and as a support to collective negotiations. In addition to the modelling work, this project involved extensive stakeholders interviews and iterative group meetings during two years (Bernhardt, et al., 2012; Guerry et al., 2012; McKenzie et al., 2014).

Overall, this NCP case study is particularly illustrative of the variety of challenges that EISC designers and users have to deal with in real-word contexts. It shows how the InVEST models and the other ad-hoc evaluative information produced in Vancouver Island have been used to guide collective decision-making and organize action in an emerging perimeter centered on a marine ecological entity and involving multiple stakeholders with heterogeneous interests and needs. In the light of this NCP example, the design and use of EISC in such emerging perimeters is comparable to some extent to issues of design and use of 
conventional management accounting tools in business and other formal organizational perimeters. Despite the fact that they are designed to be centered on ecological issues, to be used in organized action perimeters involving multiple stakeholders, and to mobilize very heterogeneous sets of metrics, EISC like the Natural Capital Project tools are equivalent to conventional management accounting systems in that they both aim at supporting planning and control activities, elaborating strategies, informing decisions, rationally managing resources, improving the management of performances, assessing and comparing overall and individual results, etc. Just as management accounting, EISC could well be defined as "a formal mechanism for gathering and communicating data for the ends of aiding and coordinating collective decisions in light of the overall goals or objectives of an organization" (Horngren and Sundem, 1990, p. 4, cited by Macintosh and Quattrone, 2010, p. 5), the challenge being however that the organizations in question differ in many ways in their goals, their functioning and their perimeters and are still to a large extent in the course of being invented, negotiated and defined (see section 6.). In other words, we can look at EISC as 'proto-accounting systems', that share their calculative nature and their ambition to inform (inter-)organizational accountabilities, but have not yet reached the level of adoption, commitment, legitimacy, durability and systematicity of organization-level or national-level accounting systems.

\section{EISC promoters are identifying important issues that could benefit from accounting research}

The Natural Capital Project, and more generally the ecosystem services community, has recently started looking back, to take stock and assess whether and how the production and communication of new information on the value and health of ecosystems in multiple contexts has so far been used and has succeeded or failed to influence decision-making and to improve biodiversity protection (Albert et al., 2014; Berghöfer et al., 2015, 2016; Booth et al., 2012; Christie et al., 2012; Cimon-Morin et al., 2013; Laurans et al., 2013; MacDonald et al., 2014; McKenzie et al., 2014; Posner, McKenzie, et al., 2016; Posner, Verutes, et al., 2016; Primmer and Furman, 2012; Rosenthal et al., 2014; Ruckelshaus et al., 2015). Yet, as Ruckelshaus et al. (2015, p. 12) recently claimed, "the promise that BES [Biodiversity and Ecosystem Services] assessments will change policy, management or practice for public or private sector is not yet proven". EISC designers and users indeed raise persistent questions, which illustrate the kind of difficulties that they face in real-world decision-making and collective organized action contexts.

Although conservation practitioners most often treat these questions as 'science-policy interface' or economic issues, we believe that they are essentially accounting issues centered on emerging and transversal perimeters rather than conventional organizational perimeters, and that they would benefit from being treated as such. For each of the four persistent questions that we have synthetized in this section, we can point to at least one related discussion area or research orientation developed by accounting research, on which new collaborations between EISC designers and accounting researchers could be developed. EISC designers could thus greatly benefit from the literature, knowledge and experience accumulated by decades of SEA and critical accounting research.

(1) What level of complexity and what quantity of information should be communicated to whom, and how, to influence decision-making and coordinate actions among multiple stakeholders? The ecological science behind the understanding of ecosystem services 
interactions and evolution is complex. However, making it count requires finding the most adequate ways to interpret, format and deliver new information, so that managers, decisionmakers and field practitioners who are not experts can make use of it in practice. This implies choosing the types of maps, indicators or temporal and geographical scales that are the most relevant to a given decision-making context, and organizing their communication. For instance, Ruckelshaus et al. (2015, p. 18) show how on Vancouver Island, "even simple average annual or ranked outputs from biodiversity and ecosystem services models can help open discussions about what are often unfamiliar issues and ways to frame policy or management objectives".

This question appears closely related to issues discussed in the large body of literature studying how the design and the roles of management accounting and control systems vary depending on the organizational context of their use and one's understanding of it (Bhimani, 2006; Chapman et al., 2008; Hopper et al., 2007; Macintosh and Quattrone, 2010). To give only one example, Macintosh and Quattrone (2010, p. 331) propose to adapt the design and use of management accounting systems to their organizational contexts depending on the existing level of definition of organizational objectives and the availability of means for action. They distinguish between management accounting systems designed to produce readymade answers or decisions and fit for contexts of high certainty ("answer machines"), those designed and used for dialogue and argumentation among managers ("ammunition machines"), those useful for exploration, learning and the generation of new ideas ("learning machine") and those used as ex-post justifications of actions and decisions ("rationalization machines"). Approaches inspired by such results would be well suited to EISC promoters in their efforts to adapt their tools to specific and heterogeneous collective action contexts for conservation.

(2) How do stakeholders and decision-makers really use the information provided in practice, and at what stage of a given management and decision-making process? How to make sure that these uses finally contribute to expected changes and decisions favorable to ecological systems? In an attempt to elucidate these issues, McKenzie et al. (2014) for instance distinguish between "conceptual", "instrumental" and "strategic" uses of ecosystem services knowledge in three different InVEST case studies (Belize, Vancouver Island, Hawaii). The authors show how these uses vary across the policy or planning process. In the Vancouver Island case study, conceptual use implied identifying unanticipated consequences of salmon aquaculture and tourism development on shellfish culture, due to their indirect role in the degradation of water quality. Instrumental use involved using coastal protection models to inform where the development of economic activities should be located in such a way that it minimizes ecological risks on coastal ecosystems. First Nations groups used some information produced by the tools in a strategic way to speak in favor of their preferred planning option.

Just as EISC users increasingly investigate how the information they provide is really used by stakeholders and decision-makers beyond their a priori expected effects, the critical accounting research agenda was founded on a similar ambition to study empirically how accounting is used in practice inside organizations beyond strongly held functionalist beliefs (Ahrens, 2009; Ahrens and Chapman, 2007; Hopwood, 1976). The SEA literature as well is structured around empirical studies. Several papers for instance describe how managers have dealt in practice with the introduction of socio-environmental accounting innovations within an organization and discuss why it often did not lead to the expected organizational and socioenvironmental changes (Bebbington and Gray, 2001; Frame and Cavanagh, 2009; Herbohn, 
2005; Larrinaga-Gonzalez et al., 2001; Larrinaga-Gonzalez and Bebbington, 2001). In their efforts to increase their reflexivity on the real uses and effects of their tools, EISC promoters could well benefit from accounting researchers' experience on the study of accounting systems/information adoption and use in practice in complex organizational settings.

(3) What types of metrics and valuation methods are legitimate and relevant for decisionmakers and stakeholders? Do they represent well the types of values that stakeholders attach to ecosystems? What are the consequences of using a given valuation approach on the organization of action and the relationships between stakeholders? Assigning monetary value estimates to ecosystem services has long been regarded as a crucial element to influence decision-making and ecosystem management (Boyd and Banzhaf, 2007; Jones-Walters and Mulder, 2009; TEEB, 2010; Turner et al., 2003; Turner and Daily, 2008). Yet, the usefulness and centrality of such metrics in real-world contexts have been increasingly challenged (Laurans et al., 2013; Mermet et al., 2014, pp. 23-54). In addition, many questions are still unresolved regarding the ability of biophysical or economic metrics to represent appropriately the diversity of worldviews associated with biodiversity (Chan et al., 2012; Kallis et al., 2013). On Vancouver Island, economic interests had to be weighed against incommensurable aesthetic or cultural values (Guerry et al., 2012). First Nations groups' priority for instance was to secure the ecological protection and the public access to specific coastal locations that have an important spiritual value. Specific metrics were developed with them to address this demand. Eventually, "ecosystem-service outputs were useful in very different currencies: from the net present value (\$) of shellfish harvested, to the spatial extent of recreational floathomes $(\mathrm{m} 2)$, to concentration $(\mathrm{g} / \mathrm{m} 3)$ of faecal coliform bacteria in the water (Guerry et al., 2012). Our partners did not want to express these values in one metric (e.g., \$)" (Ruckelshaus et al., 2015, p. 19).

Discussions on the choices and consequences of valuation methods in accounting history as well as in the introduction of new accounting systems is a key component of critical and socio-environmental accounting studies. In his work Miller (2001) for instance shows how the introduction of standard costing as well as discounting methods in investment evaluation in the early $20^{\text {th }}$ century have profoundly transformed firms' organizational processes, factories' production spaces and accountability relationships between managers and employees. In SEA research, debates on the metrics to be used in accounting innovations are often connected to the quest for new languages and for new ontological foundations of accounting systems, distinct from "the bizarre and tortured foundations of financial accounting" (Gray, 2013, p. 459) and adapted to the unique nature of socio-ecological issues (Birkin, 1996, 2000, 2003; Birkin et al., 2005; Cooper, 1992; Everett, 2004; Kaghan, 2004). Propositions are also made on ways to better integrate pluralistic representations of socio-environmental issues in accounting/information system design (Blackburn et al., 2014; Brown et al., 2005; Dillard and Yuthas, 2013). Such orientations in accounting research could be the basis of new collaborations with EISC designers, as they strive to further investigate the long-term practical and philosophical implications of their metrics and valuation choices, and as they look for EISC design methods able to articulate a plurality of worldviews and relationships to the natural environment.

(4) What are the roles of EISC promoters at the different stages of a given decisionmaking and management process, and how should they articulate their actions with other stakeholders' roles? This pertains to the level of implication that EISC designers and users should have in influencing decision and action in a way favorable to conservation. Should they just be neutral information and science providers or, on the contrary, should they actively 
engage in creating change, for instance by helping other stakeholders to negotiate ambitious ecological objectives? In the Vancouver Island example, the authors point out how iterative meetings organized by the NCP scientists helped to articulate ecosystem services knowledge with other forms of local knowledge and values. They show that this method and their personal engagement facilitated the overall decision-making process, as "the conversations identified locals' values and visions for the future of their open spaces"(McKenzie et al., 2014, p. 8).

This question appears as closely related to issues raised by the SEA literature on the roles to be played by accountants in the conduct of organizational and environmental changes. Some discussions concern how conventional accountants could (or could not) be potential vectors of socio-environmental change in their organizations (Deegan, 2013; Gray et al., 1995). Other authors argue that SEA researchers themselves are to play such a role, by promoting SEA innovations and supporting organizations' managers/employees in their experimentation (Ball, 2007; Ball and Craig, 2010), or by facilitating dialogic participatory processes where various constituencies belonging to the civic sphere are collectively involved in the design of socio-environmental accounting systems and in standard setting (Brown, 2009; Brown et al., 2015; Brown and Dillard, 2013, 2015). The SEA literature has also underlined the counter-hegemonic and alternative roles that can be played by 'external accounts' developed by social activists in socio-environmental conflict arenas (Georgakopoulos and Thomson, 2008; Thomson et al., 2015). These reflections and propositions could be of great interest to EISC promoters who also wish to play an active role in the change process by the development and use of their accounts in emerging perimeters.

\section{Investigating the organizational, institutional and political dimensions of EISC design and use}

As their reflections show, EISC promoters increasingly realize that the challenges that they face are not only due to the technical, scientific and calculative dimensions of EISC, but to their social, organizational and institutional nature. EISC essentially consist in the use of accounting systems in organizational and institutional settings. Under this premise, it is not only worth turning to accounting research to develop overlapping areas of discussion and collaboration with EISC designers, but also to start developing a research agenda applied to EISC that would be directly inspired by the one developed by critical accounting.

Critical accounting has put the study of accounting as a social and organizational phenomenon at the center of its research agenda for the past 40 years (Chapman et al., $2009 \mathrm{~b}$ ). Moving away from a purely technical and functionalist understanding of accounting tools and challenging economics as being the unique theoretical foundation of accounting research and practice (Baxter and Fong Chua, 2003; Broadbent and Laughlin, 2013; Roslender and Dillard, 2003), the critical accounting research agenda has aimed from its very beginning at studying "the diversity of those organizational linkages which ground accounting and other information and control systems into the on-going processes of organizational life" (Hopwood, 1983, p. 297). As Chapman et al. (2009b) show, critical accounting research has finally led to regard accounting as more than a simple mirror of organizational and institutional reality. Instead, accounting, organizations and institutions "should be viewed as fundamentally interrelated and interdependent, [...] the links among them should be viewed as mutually constitutive" (Ibid, p. 1). In the light of this perspective and its core intuitions, one could thus claim that to think of, to analyze, to define, to design or to use accounting 
systems is always simultaneously conceiving, analyzing, defining and establishing the accountability and organized action systems of which they are a fundamental part (Roberts, 1991; Roberts and Scapens, 1985). The profound connections between accounting, organizations and institutions have now been considerably documented by multiple empirical studies on accounting in practice (Ahrens, 2009; Ahrens and Chapman, 2006, 2007) and by the mobilization of a large spectrum of theoretical frameworks, not inherent to the accounting discipline, but coming rather from management, sociology of organizations, political science, philosophy, ethics, etc. (Baxter and Fong Chua, 2003; Covaleski and Aiken, 1986; Macintosh and Quattrone, 2010; Malmi and Granlund, 2009; Quattrone, 2009).

To further develop Accounting for the management of ecosystems, a similar approach could and should be adopted to gradually equip the collective discussion on the intimate connections between EISC on the one side, and the organizational, political and institutional dimensions of their use on the other side. As we have seen, EISC designers and users - that we might as well call 'conservation accountants' - have to deal with organizational issues that are of a significantly different nature than those encountered by conventional management accountants and that occur in accounting perimeters that are still largely 'in the making'. Just as the adoption of new conventional accounting techniques and practices leads to profound organizational transformations within firms (Ahrens and Chapman, 2007; Busco and Quattrone, 2015; Macintosh and Quattrone, 2010; Miller, 2001; Miller, P, 1992; Miller and O'Leary, 1987), new accounting for ecosystems tools and activities can have profound consequences on the collective organized action for conservation settings of which they are part and that they contribute to materialize.

Following the road taken decades ago by critical accounting researchers, the priority would be to first analyze, critique and then enrich the vision of the organizational, institutional and political realities of which conservation accountants and their accounts are part, and which their mission is to serve. One could first be tempted to look out for theories coming directly from the domains of management, sociology of organizations, economics or political science to shed light on the conditions under which conservation accounts could substantially transform organized action in a way favorable to ecological systems. Yet, chances are high that mobilizing intellectual resources coming from these fields will prove to be largely inadequate for this task. Indeed, one must consider the unique nature of both (1) ecological issues, which are most often transversal to a multiplicity of organizations, simultaneously scientific and social, often not well spatially bounded and are the direct or indirect consequence of the way society is already organized and institutionalized today; (2) and of the types of organized action systems, accountability relationships, and the forms of agency required to resolve ecological issues and conserve ecological systems. Rather than trying to transfer directly organizational models from other fields, one should clarify and improve specific organizational models to be used as the basis for organized action and for promoting accountability in the field of ecosystem conservation.

A first step in that direction consists in clarifying through reflection and critique what conceptions of organized action are already in use and underpin the work of conservation accountants. EISC promoters such as the NCP scientists are indeed well aware that issues related to the production and use of evaluative information on ecosystems cannot be addressed in total disconnection from the organizing for which their tools are developed. From our observation of the debates in the conservation community and in the EISC literature, we find for instance that three main conceptions of organized action for ecosystems dominate current discourse and practice of EISC design and use: a rational model of decision- 
making (see for instance Tallis and Polasky, 2011); pragmatic trial and error approaches in contexts where socio-economic 'enabling conditions', institutional capacity and demonstrated interest in using ecological information are already in place (see for instance Berghöfer et al., 2016; Ruckelshaus et al., 2015, p. 12; TEEB, 2012a, 2012b); participatory approaches promoting stakeholders engagement (see for instance Koschke et al., 2014; McKenzie et al., 2011, 2012). However, these conceptions (1) draw from a limited repertoire of options for understanding and designing organized action and (2) they are most of the time not made explicit by conservation account producers nor by the accounts users. This drastically reduces the scope of analyzing and acting towards a possible fit between EISC and organizational functioning. Critique and reflection to shed light on such underlying organizational models constitute an important first step to improve the links between evaluative information systems and organized action in the field of biodiversity conservation.

In view of the quite limited scope of the current prevalent models of organized action, and of the serious limitations that affect each of them, a second step will be necessary to effectively reduce the gap between the use of conservation accounts and their ability to create change in practice. We suggest here to enrich EISC users' and their to be accounting research collaborators' conception of the organizational dimensions of their accounts by extending very actively the repertoire of theories that are used to shed light on the design of EISC and accounting systems for the management of ecosystems. Indeed, because SEA researchers and ecosystem national accounting researchers mostly work on well-established accounting entities such as firms or states, they both can already rely on a large spectrum of available organizational models and theories analyzing the functioning and management of their respective entities. EISC promoters however, work on accounting entities 'in the making' that do not yet have the same level of institutionalization or historical depth as states or firms. They now need to mobilize theories that are particularly relevant in - and are developed for the very purpose of - addressing the institutional, political and organizational issues of the specific perimeters of collective action to resolve ecological issues and manage ecosystems.

For now, we will only point here to three theories that we believe could play such a role: (1) Ostrom's Common-Pool-Resources theory (Ostrom, 1990; Ostrom et al., 1994) to reflect on the design of accounting for the management of ecosystems able to support the negotiation, establishment, institutionalization and monitoring of systems of rules for the management of a shared ecological resource among multiple users; (2) Latour's Politics of Nature (Latour, 2004) to reflect on the roles that conservation accountants could play at different steps of the collective treatment and institutionalization of a new ecological entity; (3) the Strategic Environmental Management Analysis framework developed collectively in France in the 1990s (Mermet, 1992, 2011; Mermet et al., 2005, 2014, pp. 285-305; Mermet and Leménager, 2015) to reflect on the design of accounting for the management of ecosystems that can be used to support strategies for making others accountable in adversative contexts around the management of an ecological entity. Each of these theories provides very different but complementary analytical insights and useful guidance to clarify the definition of new accounting entities, the design and use of innovative EISC/conservation accounts and to better organize on their basis "systems of accountability" (Roberts, 1991; Roberts and Scapens, 1985) that are indispensable to establish a long term and robust collective management of ecological systems. 


\section{Conclusion: a research agenda for Accounting for the Management of Ecosystem}

To sum-up, in our view the on-going efforts to develop organization-centered biodiversity accounting innovations and national ecosystem accounting should be completed by a third layer of self-standing accounting innovation, centered on the organization of emerging ecological system management perimeters. We suggest referring to this agenda as Accounting for the management of ecosystems (AfME). In this perspective, EISC can be considered as new forms of ecological accounts, inserted in complex accountability relationships dynamics and used in a diversity of collective organized action settings, that can be regarded as the new accounting entities on which to focus. To go further, we suggest that directly transferring the rich heritage of accounting research to the realm of conservation would not lead to expected outcomes. The gap is too large between the types of organizational and institutional issues that have been addressed by accounting research for decades, and the kinds of organizational and institutional contexts faced by conservation practitioners who use EISC in their attempts to solve ecological issues.

To close this gap between accounting research and ecological issues management, we believe that two things are required. First, we need to mobilize the concepts, methods and findings developed by critical accounting research in its quest for a refined understanding of the intimate connections between the social, organizational and political dimensions of accounting systems. Critical accounting as well as SEA can provide (1) in depth treatment of key accounting concepts such as the definition of accounting entities and perimeters, the understanding of systems of accountability, the transformative power of the use of calculative practices, the roles played by accountants in organizational functioning, etc.; (2) the experience of a research field on organizations and accounting systems built on both empirical field studies and the mobilization of a large spectrum of theories coming from various other disciplines. This accumulated knowledge and experience in the field of accounting can be the basis of rich discussions and applied collaborative research between accounting researchers and those in the field of conservation who develop innovative EISC and use them in various collective action contexts to obtain ecological results. Secondly, for critical accounting insights to be relevant in the realm of ecological systems conservation, they need to be combined with theoretical resources specifically relevant for the types of organized action and accountability systems that need to be established to resolve such ecological issues. As we have suggested in this paper, this should rest on the first hand on criticizing prevalent (and often implicit) conceptions of organized action underlying the current use of EISC, and on the other hand on the use of more explicit and more powerful conceptual models and theories.

Overall, we think that four main characteristics make all the difference between EISC doomed to remain 'proto-accounting' systems (i.e. not well connected to organized conservation action in the appropriate perimeters) and EISC designed and used as full-fledged accounting systems for emerging perimeters of collective ecosystem management: (1) the use of evaluative information and calculative practices in a way that establishes or strengthens reciprocal commitments among various organizations concerned by a shared ecological issue; (2) the possibility to effectively enforce these inter-organizational accountabilities through accounts exchange; (3) the periodicity of account exchange practices and their maintenance over time; (4) the gradual routinization and technical equipment of these accountabilities and associated organizational practices. 
By designing and treating EISC as Accounting for the management of ecosystems, that is by recognizing and studying their profound connections to organized action and their institutional, political and organizational dimensions, it will become possible to articulate organization-centered accounting for biodiversity innovations and ecosystem accounting at the national scale with their missing link: the gradual institutionalization of collective regimes of accountabilities centered on ecological issues in emerging perimeters. Such an articulation under the shared umbrella of accounting, both as a technical and practical field specialized in the design and use of calculative information systems and as a well-equipped critical domain of social science research, will open the door to an investigation of the problem of global biodiversity conservation as an issue of accountability at all scales and across current formal organizational and institutional boundaries.

\section{Bibliography}

Ahrens, T. (2009), "Everyday Accounting Practices and Intentionality", in Chapman, C.S., Cooper, D.J. and Miller, P. (Eds.), Accounting, Organizations, and Institutions. Essays in Honour of Anthony Hopwood, Oxford University Press, New York, pp. 30-47.

Ahrens, T., Becker, A., Burns, J., Chapman, C.S., Granlund, M., Habersam, M., Hansen, A., Khalifa, R., Malmi, T., Mennicken, A., Mikes, A., Panozzo, F., Piber, M., Quattrone, P. and Scheytt T. (2008), "The future of interpretive accounting research-A polyphonic debate", Critical Perspectives on Accounting, Vol. 19 No. 6, pp. 840-866.

Ahrens, T. and Chapman, C.S. (2006), "Doing qualitative field research in management accounting: Positioning data to contribute to theory", Accounting, Organizations and Society, Vol. 31, No.8. pp. 819-841.

Ahrens, T. and Chapman, C.S. (2007), "Management accounting as practice", Accounting, Organizations and Society, Vol. 32 No. 1-2, pp. 1-27.

Albert, C., Hauck, J., Buhr, N. and von Haaren, C. (2014), "What ecosystem services information do users want? Investigating interests and requirements among landscape and regional planners in Germany", Landscape Ecology, Vol. 29 No. 8, pp. 1301-1313.

Allen, B.G. (2014), "What's new about New accounts? Assessing change proposals for social and environmental accounting", Accounting Forum, Vol. 38 No. 4, pp. 278-287.

Arkema, K.K., Guannel, G., Verutes, G., Wood, S.A., Guerry, A., Ruckelshaus, M., Kareiva, P., Lacayo, M. and Silver, J.M. (2013), "Coastal habitats shield people and property from sealevel rise and storms", Nature Climate Change, Vol. 3, pp. 913-918.

Armstrong, P. (2008), "Calling out for more: Comment on the future of interpretive accounting research", Critical Perspectives on Accounting, Vol. 19 No. 6, pp. 867-879.

Atkins, J., Gräbsch, C. and Jones, M. (2014), "Corporate biodiversity reporting: exploring its anthropocentric nature", in Jones, M.J. (Ed.), Accounting for Biodiversity, Routledge, Oxon, pp. 215-244.

Bagstad, K.J., Semmens, D.J., Waage, S. and Winthrop, R. (2013), "A comparative 
assessment of decision-support tools for ecosystem services quantification and valuation", Ecosystem Services, Vol. 5, pp. 27-39.

Ball, A. (2007), "Environmental accounting as workplace activism", Critical Perspectives on Accounting, Vol. 18 No. 7, pp. 759-778.

Ball, A. and Craig, R. (2010), "Using neo-institutionalism to advance social and environmental accounting", Critical Perspectives on Accounting, Vol. 21 No. 4, pp. 283-293.

Baxter, J., Boedker, C. and Chua, W.F. (2008), "The future(s) of interpretive accounting research-A polyphonic response from beyond the metropolis", Critical Perspectives on Accounting, Vol. 19 No. 6, pp. 880-886.

Baxter, J. and Fong Chua, W. (2003), "Alternative management accounting research Whence and whither", Accounting, Organizations and Society, Vol. 28 No. 2-3, pp 97 -126.

Bebbington, J. and Gray, R. (2001), "An Account of Sustainability: Failure, Success and a Reconceptualization”, Critical Perspectives on Accounting, Vol. 12 No. 5, pp. 557-588.

Bebbington, J. and Larrinaga, C. (2014), "Accounting, Organizations and Society Accounting and sustainable development: An exploration", Accounting, Organizations and Society, Vol. 39 No. 6, pp. 395-413.

Berghöfer, A., Brown, C., Bruner, A., Emerton, L., Esen, E., Geneletti, D., Kosmus, M., Kumar, R., Lehmann, M., Morales, F.L., Nkonja, E., Pistorius, T., Rode, J., Slootweg, R., Tröger, U., Wittmer, H., Wunder, S. and van Zyl, H.. (2016), Increasing the Policy Impact of Ecosystem Service Assessments and Valuations - In-Sights from Practice, ValuES project, p. 30.

Berghöfer, A., Wittich, A., Wittmer, H., Emerton, L., Kosmus, M. and van Zyl, H. (2015), Synthesis of the ValuES Analysis of 19 Ecosystem Service Assessments for Different Purposes - Insights from Practical Experience, ValuES Project Report, Helmholtz-Zentrum für Umweltforschung (UFZ) GmbH, Leipzig, and Deutsche Gesellschaft für Internationale Zusammenarbeit (GIZ) GmbH, Eschborn, Germany, Germany, p. 26.

Bernhardt, J., Guerry, A., McKenzie, E., Toft, J. and Wood, S.A. (2012), InVEST Scenarios Case Study: Vancouver Island, Canada, World Wildlife Fund and Natural Capital Project, available at: http://www.naturalcapitalproject.org/pubs/Vancouver_CS.pdf.

Bhagabati, A.N., Barano, T., Conte, M., Ennaanay, D., Hadian, O., Mckenzie, E., Olwero, N., et al. (2012), A Green Vision for Sumatra: Using Ecosystem Services Information to Make Recommendations for Sustainable Land Use Planning at the Province and District Level, The Natural Capital Project, WWF-US, and WWF-Indonesia.

Bhimani, A. (Ed.). (2006), Contemporary Issues in Management Accounting, Oxford University Press, Oxford.

Birch, J.C., Thapa, I., Balmford, A., Bradbury, R.B., Brown, C., Butchart, S.H.M., Gurung, H., Hughes, F.M.R., Mulligan, M., Pandeya, B., Peh, K.S.-H., Stattersfield, A.J., Walpole, M. and Thomas, D.H.L.. (2014), "What benefits do community forests provide, and to whom ? A 
rapid assessment of ecosystem services from a Himalayan forest , Nepal", Ecosystem Services, Vol. 8, pp. 118-127.

Birkin, F. (1996), "The ecological accountant: from the cogito to thinking like a mountain", Critical Perspectives on Accounting, Vol. 7, No. 3. pp. 231-257.

Birkin, F. (2000), "The art of accounting for science: A prerequesite for sustainable development?”, Critical Perspectives on Accounting, Vol. 11 No. July 1999. pp. 289-309.

Birkin, F. (2003), "Ecological accounting: new tools for a sustainable culture", International Journal of Sustainable Development and World Ecology, Vol. 10 No. 1, pp. 49-61.

Birkin, F., Edwards, P. and Woodward, D. (2005), "Accounting's contribution to a conscious cultural evolution: an end to sustainable development", Critical Perspectives on Accounting, Vol. 16 No. 3, pp. 185-208.

Blackburn, N., Borwn, J., Dillard, J. and Hooper, V. (2014), “A Dialogic Framing of AISSEA Design”, International Journal of Accounting Information Systems, Vol. 15 No. 2, pp. 83-101.

BoM. (2013), Guide to Environmental Accounting in AUstralia, Environmental Information Programme Publication Series No. 3, Bureau of Meteorology, Canberra, Australia, p. 122.

Booth, H., Simpson, L., Ling, M., Mohammed, O., Brown, C., Garcia, K. and Walpole, M. (2012), Lessons Learned from Carrying out Ecosystem Assessments: Experiences from Members of the Sub-Global Assessment Network, UNEP-WCMC, Cambridge.

Borsato, R., Mendes Filho, J.T., Milano, M.S., Salzmann, A.M., Brasil, B., Alexandre, M.A., De Lourdes Silva Nunes, M., et al. (2014), "Biodiversity accountability in Brazil: the role of LIFE Certification", in Jones, M.J. (Ed.), Accounting for Biodiversity, Routledge, Oxon, pp. $172-188$.

Borucke, M., Moore, D., Cranston, G., Gracey, K., Katsunori, I., Larson, J., Lazarus, E., et al. (2013), "Accounting for demand and supply of the biosphere's regenerative capacity: The National Footprint Accounts' underlying methodology and framework", Ecological Indicators, Vol. 24, pp. 518-533.

Bouni, C. (1996), Développement Durable et Macro-Systèmes D’information: Des Comptes D'environnement À L'aide Multi-Critère À La Décision, Economie, Université de Paris I Panthéon-Sorbonne.

Boyd, J. and Banzhaf, S. (2007), "What are ecosystem services? The need for standardized environmental accounting units", Ecological Economics, Vol. 63 No. 2-3, pp. 616-626.

Broadbent, J. and Laughlin, R. (2013), Accounting Control and Controlling Accounting: Interdisciplinary and Critical Perspectives, Emerald Publishing.

Brown, D., Dillard, J. and Marshall, S. (2005), "Incorporating Natural Systems as Part of Accounting's Public Interest Responsibility”, Journal of Information Systems, Vol. 19 No. 2, pp. 79-104. 
Brown, J. (2009), "Democracy, sustainability and dialogic accounting technologies: Taking pluralism seriously", Critical Perspectives on Accounting, Vol. 20 No. 3, pp. 313-342.

Brown, J. and Dillard, J. (2013), "Agonizing over engagement: SEA and the 'death of environmentalism' debates”, Critical Perspectives on Accounting, Vol. 24 No. 1, pp. 1-18.

Brown, J. and Dillard, J. (2015), "Dialogic accountings for stakeholders: O, opening up and closing down participatory governance", Journal of Management Studies, Vol. 52 No. 7, pp. 961-985.

Brown, J., Dillard, J. and Hopper, T. (2015), "Accounting, accountants, and accountability regimes in pluralistic societies: taking multile perspectives seriously", Accounting , Auditing \& Accountability Journal, Vol. 28 No. 5, pp. 626-650.

Busco, C. and Quattrone, P. (2015), "Exploring How the Balanced Scorecard Engages and Unfolds: Articulating the Visual Power of Accounting Inscriptions", Contemporary Accounting Research, Vol. 32 No. 3, pp. 1236-1262.

Cabral, P., Feger, C., Levrel, H., Chambolle, M. and Basque, D. (2016), "Assessing the impact of land-cover changes on ecosystem services: A first step toward integrative planning in Bordeaux, France", Ecosystem Services, Vol. 22, pp. 318-327.

Callicott, J.B., Crowder, L.B. and Mumford, K. (1999), "Current normative concepts in conservation", Conservation Biology, Vol. 13 No. 1, pp. 22-35.

Campbell, E.T. and Tilley, D.R. (2014), "Valuing ecosystem services from Maryland forests using environmental accounting”, Ecosystem Services, Vol. 7, pp. 141-151.

Chan, K.M.A., Guerry, A.D., Balvanera, P., Klain, S., Satterfield, T., Bostrom, A., Chuenpagdee, R., et al. (2012), "Where are Cultural and Social in Ecosystem Services? A Framework for Constructive Engagement”, BioScience, Vol. 62 No. 8, pp. 744-756.

Chapman, C., Hopwood, A. and Shields, M. (2008), Handbook of Management Accounting Research, Vol. 2, Elsevier, Oxford.

Chapman, C.S., Cooper, D.J. and Miller, P. (Eds.). (2009a), Accounting, Organizations, and Institutions. Essays in Honour of Anthony Hopwood, Oxford University Press, New York.

Chapman, C.S., Cooper, D.J. and Miller, P.B. (2009b), "Linking Accounting, Organizations, and Institutions", in Chapman, C.S., Cooper, D.J. and Miller, P. (Eds). Accounting, Organizations, and Institutions. Essays in Honour of Anthony Hopwood, Oxford University Press, New York, pp. 1-29.

Chaveriat, C., Ghitalla, F., Pelegrin, F., Fadil, F. and Le Roux, X. (2011), La Base de Données Nationales Des Acteurs, Structures et Projets de Recherche Sur La Biodiversité: Présentation et Analyse Du Paysage de La Recherche, Rapport FRB, Fondation pour la Recherche sur la Biodiversité, Série Expertise et Synthèse, p. 36.

Chisholm, R.A. (2010), “Trade-offs between ecosystem services: Water and carbon in a 
biodiversity hotspot”, Ecological Economics, Vol. 69 No. 10, pp. 1973-1987.

Christie, M., Fazey, I., Cooper, R., Hyde, T. and Kenter, jasperO. (2012), “An evaluation of monetary and non-monetary techniques for assessing the importance of biodiversity and ecosystem services to people in countries with developing economies", Ecological Economics, Vol. 83, pp. 67-78.

Cimon-Morin, J., Darveau, M. and Poulin, M. (2013), "Fostering synergies between ecosystem services and biodiversity in conservation planning: A review", Biological Conservation, Vol. 166, pp. 144-154.

Cooper, C. (1992), "The Non and Nom of Accounting for ( M ) other Nature", Accounting , Auditing \& Accountability Journal, Vol. 5 No. 3, pp. 16-39.

Covaleski, M. and Aiken, M. (1986), "Accounting and theories of organizations: some preliminary considerations", Accounting, Organizations and Society, Vol. 11 No. 4/5, pp. 297-319.

Crozier, M. and Friedberg, E. (1995), "Organizations and collective action: our contribution to organizational analysis", in Bacharach, S.., Gagliardi, P. and Mundell, B. (Eds.), Research in the Sociology of Organizations: Studies of Organizations in the European Tradition, Vol. 13, JAI Press, Greenwich, pp. 71-92.

Cuckston, T. (2013), "Bringing tropical forest biodiversity conservation into financial accounting calculation", Accounting, Auditing \& Accountability Journal, Vol. 26 No. 5, pp. $688-714$.

Cullen, D. and Whelan, C. (2006), "Environmental Management Accounting: The State of Play”, Journal of Business \& Economic Research, Vol. 4 No. 10, pp. 1-6.

Daily, G.C., Kareiva, P.M., Polasky, S., Ricketts, T.H. and Tallis, H. (2011), "Mainstreaming natural capital into decisions", Natural Capital. Theory and Practice of Mapping Ecosystem Services, Oxford University Press, New York, pp. 3-14.

Daily, G.C., Polasky, S., Goldstein, J., Kareiva, P.M., Mooney, H.A., Pejchar, L., Ricketts, T.H., et al. (2009), in Kareiva, P., Tallis, H., Ricketts, T.H., Daily, G.C. and Polasky, S. (Ed.), "Ecosystem services in decision making: time to deliver", Frontiers in Ecology and the Environment, Vol. 7 No. 1, pp. 21-28.

Dale, V.H. and Beyeler, S.C. (2001), "Challenges in the development and use of ecological indicators", Ecological Indicators, Vol. 1 No. 1, pp. 3-10.

Davies, J. (2014), "Full cost accounting - integrating biodiversity", in Jones, M.. (Ed.), Accounting for Biodiversity, Routledge, Oxon, pp. 81-102.

Deegan, C. (2013), "The accountant will have a central role in saving the planet...really? A reflection on 'green accounting and green eyeshades twenty years later'", Critical Perspectives on Accounting, Vol. 24 No. 6, pp. 448-458.

Dey, C. and Russell, S. (2014), "Who speaks for the river? Exploring biodiversity accounting 
using an arena approach", in Jones, M.. (Ed.), Accounting for Biodiversity, Routledge, Oxon, pp. 245-266.

Dillard, J. and Yuthas, K. (2013), "Critical dialogics, agonistic pluralism, and accounting information systems", International Journal of Accounting Information Systems, Vol. 14, No. 2, pp. 113-119.

EC. (2013), System of Environmental-Economic Accounting 2012. Experimental Ecosystem Accounting, European Commission, Organisation for Economic Co-operation and Development, United Nations, World Bank, available at: https://unstats.un.org/unsd/envaccounting/eea_white_cover.pdf.

Edens, B. and Hein, L. (2013), "Towards a consistent approach for ecosystem accounting”, Ecological Economics, Vol. 90, pp. 41-52.

Elad, C. (2014), "Forest certification and biodiversity accounting in the Congo basin countries", in Jones, M.. (Ed.), Accounting for Biodiversity, Routledge, Oxon, pp. 189-211.

Eugénio, T., Lourenço, I.C. and Morais, A.I. (2010), "Recent developments in social and environmental accounting research", Social Responsibility Journal, Vol. 6 No. 2, pp. 286305.

Eurostat. (2002), European Framework for Integrated Environmental and Economic Accounting for Forests - IEEAF, Office for Official Publications of the European Communities, Luxembourg.

Everett, J. (2004), "Exploring (false) dualisms for environmental accounting praxis", Critical Perspectives on Accounting, Vol. 15 No. 8, pp. 1061-1084.

Feger, C. (2016), Nouvelles Comptabilités Au Service Des Écosystèmes. Une Recherche Engagée Auprès D’une Entreprise Du Secteur de L'environnement., Sciences de gestion, AgroParisTech, Paris, February.

Feger, C., Cabral, P., Basque, D., Levrel, H. and Chambolle, M. (2015), "Grand cycle de l'eau, évaluation des services écosystémiques et aménagement du territoire: un premier retour d'expérience", Techniques Sciences Méthodes, Vol. 9, pp. 56-57.

Frame, B. and Cavanagh, J. (2009), "Experiences of sustainability assessment: An awkward adolescence", Accounting Forum, Vol. 33 No. 3, pp. 195-208.

Georgakopoulos, G. and Thomson, I. (2008), "Social reporting, engagements, controversies and conflict in an arena context", Accounting, Auditing \& Accountability Journal, Vol. 21 No. 8, pp. $1116-1143$.

Goldstein, J.H., Caldarone, G., Duarte, T.K., Ennaanay, D., Hannahs, N., Mendoza, G., Polasky, S., et al. (2012), "Integrating ecosystem-service tradeoffs into land-use decisions", Proceedings of the National Academy of Sciences of the United States of America, Vol. 109 No. 19, pp. 7565-70.

Gray, R. (1992), “Accounting and environmentalism: an exploration of the challenge of 
gently accounting for accountability, transparency and sustainability", Accounting, Organizations and Society, Vol. 17 No. 5, pp. 399-425.

Gray, R. (2007), "Taking a Long View on What We Now Know About Social and Environmental Accountability and Reporting", Issues in Social and Environmental Accounting, Vol. 1 No. 2, pp. 169-198.

Gray, R. (2008), "Social and Environmental Accounting and Reporting: From Ridicule to Revolution? From Hope to Hubris? - A Personal Review of the Field", Issues in Social and Environmental Accounting, Vol. 2 No. 1, pp. 3-18.

Gray, R. (2010), "Is accounting for sustainability actually accounting for sustainability...and how would we know? An exploration of narratives of organisations and the planet", Accounting, Organizations and Society, Vol. 35, No. 1. pp. 47-62.

Gray, R. (2013), "Back to basics: What do we mean by environmental (and social) accounting and what is it for?-A reaction to Thornton", Critical Perspectives on Accounting, Vol. 24 No. 6, pp. 459-468.

Gray, R., Adams, C.A. and Owen, D. (2014), Accountability, Social Responsibility and Sustainability: Accounting for Society and the Environment, Pearson, Harlow, UK.

Gray, R., Brennan, A. and Malpas, J. (2014), "New accounts : Towards a reframing of social accounting", Accounting Forum, Vol. 38 No. 4, pp. 258-273.

Gray, R., Walters, D., Bebbington, J. and Thompson, I. (1995), "The greening of enterprise: An exploration of the (non) role of environmental accounting and environmental accountants in organizational change", Critical Perspectives on Accounting, Vol. 6, No 3. pp. 211-239.

GRI. (2011), Approach for Reporting on Ecosystem Services. Incorporating Ecosystem Services into an Organization's Performance Disclosure, Global Reporting Initiative, available at: https://www.globalreporting.org/resourcelibrary/Approach-for-reporting-onecosystem-services.pdf.

Guerry, A.D., Arkema, K.K., Bernhardt, J.R., Guannel, G., Kim, C., Marsik, M., Papenfus, M., et al. (2012), "Modeling benefits from nature : using ecosystem services to inform coastal and marine spatial planning", International Journal of Biodiversity Science, Ecosystem Services and Management, Vol.8 No. 1-2, pp.107-121.

Gundimeda, H., Sukhdev, P., Sinha, R.K. and Sanyal, S. (2007), "Natural resource accounting for Indian states - Illustrating the case of forest resources", Ecological Economics, Vol. 61, No. 4. pp. 637-649.

Hanson, C., Van Der Lugt, C. and Ozment, S. (2011), Nature in Performance: Initial Recommendations for Integrating Ecosystem Services into Business Performance System, World Resources Institute, Washington, D. C.

Havas, J., Matsui, T., Shaw, R.N. and Machimura, T. (2014), "Ecosystem services management tool development guidelines and framework revision for industries, industry policy makers and industry groups", Ecosystem Services, Vol. 7, pp. 187-200. 
Heink, U. and Kowarik, I. (2010), "What are indicators? On the definition of indicators in ecology and environmental planning”, Ecological Indicators, Vol. 10 No. 3, pp. 584-593.

Hein, L., Obst, C., Edens, B. and Remme, R.. (2015), "Progress and challenges in the development of ecosystem accounting as a tool to analyse ecosystem capital", Current Opinion in Environmental Sustainability, Vol. 14, pp. 86-92.

Herbohn, K. (2005), "A full cost environmental accounting experiment", Accounting, Organizations and Society, Vol. 30 No. 6, pp. 519-536.

Hopper, T., Scapens, R.W. and Northcott, D. (2007), Issues in Management Accounting, Pentice Hall, Financial Times., 3, London.

Hopwood, A.. (1983), "On trying to study accounting in the contexts in which it operates", Accounting, Organizations and Society, Vol. 8, No. 2-3. pp. 287-305.

Hopwood, A.G. (1976), "Editorial: Accounting, Organizationsand Society", Accounting, Organizations and Society, Vol. 1 No. 1, pp. 1-4.

Hopwood, G. (2007), “Whither Accounting Research?”, The Accounting Review, Vol. 82 No. 5, pp. 1365-1374.

Horngren, C.T. and Sundem, G.L. (1990), Introduction to Management Accounting, PrenticeHall, New Jersey, Englewoods Cliffs.

Houdet, J. (2010), Entreprises, Biodiversité et Services Écosystémiques. Quelles Interactions et Stratégies? Quelles Comptabilités?, Sciences de gestion, AgroParisTech.

Houdet, J. (2012), Le Bilan Biodiversité. Une Méthodologie Pour Intégrer La Nature Dans Votre Comptabilité, Naturparif., Victoires Editions, Paris.

Houdet, J. and Germaneau, C. (2014), "Accounting for biodiversity and ecosystem services from an EMA perspective: towards a standardised biodiversity footprint methodology", in Jones, M.. (Ed.), Accounting for Biodiversity, Routledge, Oxon, pp. 62-80.

Ionescu, C. (2016), Biodiversité et Stratégie Des Organisations : Construire Des Outils Pour Gérer Des Relations Multiples et Inter-Temporelles, Economies et finances, Grenoble Alpes, France.

Jones, M. (2014a), Accounting for Biodiversity, Routledge, Oxon.

Jones, M. (2014b), “Accounting for biodiversity: rationale and overview”, in Jones, M. (Ed.), Accounting for Biodiversity, Routledge, Oxon, pp. 3-20.

Jones, M. (2014c), "Creating a theoretical framework for biodiversity accounting", in Jones, M. (Ed.), Accounting for Biodiversity, Routledge, Oxon, pp. 23-38.

Jones, M.J. (1996), “Accounting for biodiversity : a pilote study", British Accounting Review, Vol. 28 No. 4, pp. 281-303. 
Jones, M.J. (2003), “Accounting for biodiversity: operationalising environmental accounting”, Accounting, Auditing \& Accountability Journal, Vol. 16 No. 5, pp. 762-789.

Jones, M.J. and Solomon, J.F. (2013), "Problematising accounting for biodiversity", Accounting, Auditing \& Accountability Journal, Vol. 26 No. 5, pp. 668-687.

Jones-Walters, L. and Mulder, I. (2009), "Valuing nature: The economics of biodiversity", Journal for Nature Conservation, Vol. 17 No. 4, pp. 245-247.

Jørgensen, S.E., Burkhard, B. and Müller, F. (2013), "Twenty volumes of ecological indicators - An accounting short review", Ecological Indicators, Vol. 28, pp. 4-9.

Kaghan, W. (2004), "Accounting practices and networks of accountancy: a comment on 'What is measured counts' by Kala Saravanamuthu", Critical Perspectives on Accounting, Vol. 15 No. 3, pp. 325-329.

Kallis, G., Gómez-Baggethun, E. and Zografos, C. (2013), "To value or not to value? That is not the question”, Ecological Economics, Vol. 94, pp. 97-105.

Kareiva, P. and Marvier, M. (2012), "What Is Conservation Science?", BioScience, Vol. 62 No. 11, pp. 962-969.

Kareiva, P., Tallis, H., Ricketts, T.H., Daily, G.C. and Polasky, S. (2011), Natural Capital. Theory and Practice of Mapping Ecosystem Services, Oxford University Press, New York.

Kering. (2015), Kering Environmental Profit \& Loss (E P\&L). Methodology \& 2013 Group Results, Kering, available at: www.kering.com/en/sustainability.

Khan, T. (2014), “Kalimantan's biodiversity: developing accounting models to prevent its economic destruction", Accounting, Auditing \& Accountability Journal, Vol. 27 No. 1, pp. $150-182$.

Koschke, L., Van der Meulen, S., Frank, S., Schneidergruber, A., Kruse, M., Fürst, C., Neubert, E., et al. (2014), "Do You Have 5 Minutes To Spare? - The Challenges Of Stakeholder Processes In Ecosystem Services Studies", Landscape Online, Vol. 37 No. April, pp. 1-25.

Kurunmaki, L. (1999), "Making an accounting entity: the case of the hospital in Finnish health care reforms", European Accounting Review, Vol. 8 No. 2, pp. 219-237.

Larrinaga-Gonzalez, C. and Bebbington, J. (2001), "Accounting change or institutional appropriation?-A case study of the implementation of environmental accounting", Critical Perspectives on Accounting, Vol. 12 No. 3, pp. 269-292.

Larrinaga-Gonzalez, C., Carrasco-Fenech, F., Caro-Gonzalez, F., Correa-Ruiz, C. and PaezSandubete, J. (2001), "The role of environmental accounting in organizational change. An exploration of Spanish companies.", Accounting, Auditing \& Accountability Journal, Vol. 14 No. 2, pp. 213-39. 
Latour, B. (2004), Politics of Nature: How to Bring the Sciences into Democracy, Harvard University Press, Cambridge, MA.

Laurans, Y., Rankovic, A., Billé, R., Pirard, R. and Mermet, L. (2013), "Use of ecosystem services economic valuation for decision making: Questioning a literature blindspot", Journal of Environmental Management, Vol. 119, pp. 208-219.

Van Liempd, D. and Busch, J. (2013), "Biodiversity reporting in Denmark", Accounting, Auditing \& Accountability Journal, Vol. 26 No. 5, pp. 833-872.

MacDonald, D.H., Bark, R.D. and Coggan, A. (2014), "Is ecosystem service research used by decision-makers? A case study of the Murray-Darling Basin, Australia", Landscape Ecology, Vol. 29 No. 8, pp. 1447-1460.

Macintosh, N. and Quattrone, P. (2010), Management Accounting and Control Systems. An Organizational and Sociological Approach, 2nd ed., John Wiley \& Sons Ltd, West Sussex, UK.

Mäler, K.-G., Aniyar, S. and Jansson, A. (2008), "Accounting for Ecosystem Services as a Way to Understand the Requirements for Sustainable Development", Proceedings of the National Academy of Sciences of the United States of America, Vol. 105 No. 28, pp. 95019606.

Malmi, T. and Granlund, M. (2009), "In Search of Management Accounting Theory", European Accounting Review, Vol. 18 No. 3, pp. 597-620.

Mascia, M.B., Brosius, J.P., Dobson, T.A., Forbes, B.C., Mckean, M.A. and Turner, N.J. (2003), "Conservation and the Social Sciences", Conservation Biology, Vol. 17 No. 3, pp. 649-650.

Mathews, M.R. (1997), "Twenty-five years of social and environmental accounting research: Is there a silver jubilee to celebrate?", Accounting, Auditing \& Accountability Journal, Vol. 10 No. 4 , pp. $481-531$.

Mathews, M.R. (2000), The Development of Social and Environmental Accounting Research 1995-2000, Discussion paper series No. 205, School of Accountancy, Massey University, Palmerston, New Zealand, p. 44.

McKenzie, E., Irwin, F., Ranganathan, J., Hanson, C., Kousky, C., Bennett, K., Ruffo, S., et al. (2011), "Incorporating ecosystem services into decisions", in Kareiva, P., Tallis, H., Ricketts, T.H., Daily, G.C. and Polasky, S. (Eds.), Natural Capital. Theory and Practice of Mapping Ecosystem Services, Oxford University Press, New York, pp. 339-355.

McKenzie, E., Posner, S., Tillmann, P., Bernhardt, J.R., Howard, K. and Rosenthal, A. (2014), "Understanding the use of ecosystem service knowledge in decision making: lessons from international experiences of spatial planning", Environment and Planning C: Government and Policy, Vol. 32 No. 2, pp. 320-340.

McKenzie, E., Rosenthal, A., Bernhardt, J., Girvetz, E., Kovacs, K., Olwero, N. and Toft, J. (2012), Developing Scenarios to Assess Ecosystem Service Tradeoffs: Guidance and Case 
Studies for InVEST Users, World Wildlife Fund, Washington, D.C.

MEA. (2005), Millennium Ecosystem Assessment. Ecosystems and Human Well-Being: Synthesis, Island Press., Washington, D. C., available at: http://www.millenniumassessment.org/en/index.html.

Mermet, L. (1992), Stratégies Pour La Gestion De L'environnement - La Nature Comme Jeu De Société, L'Harmattan, Paris.

Mermet, L. (2011), "Strategic Environmental Management Analysis : Addressing the Blind Spots of Collaborative Approaches”, Iddri - Pour Le Débat, Vol. 11 No. 05.

Mermet, L., Billé, R., Leroy, M., Narcy, J. and Poux, X. (2005), "L'analyse stratégique de la gestion environnementale: un cadre théorique pour penser l'efficacité en matière d'environnement", Natures Sciences Sociétés, Vol. 13, pp. 127-137.

Mermet, L., Homewood, K., Dobson, A. and Billé, R. (2013), "Five paradigms of collective action underlying the human dimension of conservation", in Mcdonald, D.W. and Willis, K.J. (Eds.), Key Topics in Conservation Biology 2, Wiley-Blackwell, Oxford, pp. 42-58.

Mermet, L., Laurans, Y. and Leménager, T. (2014), Tools for What Trade? Utilization of Economic Instruments and Valuations in Biodiversity Management, Agence Française de Développement, Paris, available at: http://www.afd.fr/jahia/webdav/site/afd/shared/PUBLICATIONS/RECHERCHE/Scientifique s/A-savoir/25-VA-A-Savoir.pdf.

Mermet, L. and Leménager, T. (2015), Development and Biodiversity: Navigating the Environmental Turning Point, Agence Française de Développement, Paris, available at: http://www.afd.fr/jahia/webdav/site/afd/shared/PUBLICATIONS/RECHERCHE/Scientifique s/Recherches/04-VA-Recherches.pdf.

Miller, P. (1992), "Accounting and Objectivity: The Invention of Calculating Selves and Calculable Spaces”, Annals of Scholarship, Vol. 9 No. 1/2, pp. 61-85.

Miller, P. (2001), “Governing by Numbers: Why Calculative Practices Matter”, Social Research, Vol. 68 No. 2.

Miller, P. and O'Leary, T. (1987), "Accounting and the construction of the governable person”, Accounting, Organizations and Society, Vol. 12 No. 3, pp. 235-265.

Milne, M. (2007), "Downsizing Reg (me and you)! Addressing the 'real' sustainability agenda at work and home", in Gray, R., Guthrie, J. (Eds), Mega Accounting and Beyond: A Festschrift in Honour of MR Mathews, The Centre for Social and Environmental Accounting Research, St. Andrews, pp. 49-66.

Milne, M.J. (1991), “Accounting, environmental resource values, and non-market valuation techniques for environmental resources: A review", Accounting, Auditing \& Accountability Journal, Vol. 4 No. 3, pp. 81-109.

Milne, M.J. (1996), "On sustainability, the environment and management accounting", 
Milne, M.J. and Gray, R. (2013), "W(h)ither ecology? The triple bottom line, the global reporting initiative, and corporate sustainability reporting", Journal of Business Ethics, Vol. 118 No. 1, pp. 13-29.

Milne, M.J., Tregidga, H. and Walton, S. (2009), "Words not actions! The ideological role of sustainable development reporting", Accounting, Auditing \& Accountability Journal, Vol. 22 No. 8, pp. 1211-1257.

Müller, F. and Burkhard, B. (2012), "The indicator side of ecosystem services", Ecosystem Services, Vol. 1 No. 1, pp. 26-30.

Naro, G. (2010), "Perspectives critiques en comptabilité: le nouveau management public en question", in Palpacuer, F., Leroy, M. and Naro, G. (Eds.), Management, Mondialisation et Écologie. Regards Critiques En Sciences de Gestion, Hermes Science Publications, Paris, pp. 185-213.

NCC. (2016), Natural Capital Protocol, Natural Capital Coalition, available at: www.naturalcapitalcoalition.org/protocol.

Nelson, E., Mendoza, G., Regetz, J., Polasky, S., Tallis, H., Cameron, Dr., Chan, K.M., et al. (2009), "Modeling multiple ecosystem services, biodiversity conservation, commodity production, and tradeoffs at landscape scales", Frontiers in Ecology and the Environment, Vol. 7 No. 1, pp. 4-11.

Niemeijer, D. and de Groot, R.S. (2008), "A conceptual framework for selecting environmental indicator sets”, Ecological Indicators, Vol. 8 No. 1, pp. 14-25.

Onaindia, M., Fernández de Manuel, B., Madariaga, I. and Rodríguez-Loinaz, G. (2013), "Cobenefits and trade-offs between biodiversity, carbon storage and water flow regulation", Forest Ecology and Management, Vol. 289, pp. 1-9.

Ostrom, E. (1990), Governing the Commons. The Evolution of Institutions for Collective Action, Cambridge University Press, New York.

Ostrom, E., Gardner, R. and Walker, J. (1994), Rules, Games, and Common-Pool Resources, University of Michigan Press, Ann Arbor, MI.

Owen, D. (2008), "Chronicles of wasted time? A personal reflection on the current state of, and future prospects for, social and environmental accounting research", Accounting, Auditing \& Accountability Journal, Vol. 21 No. 2, pp. 240-267.

Parker, L.D. (2005), "Social and environmental accountability research: A view from the commentary box", Accounting, Auditing \& Accountability Journal, Vol. 18 No. 6, pp. 842860.

Parker, L.D. (2008), "Interpreting interpretive accounting research", Critical Perspectives on Accounting, Vol. 19 No. 6, pp. 909-914. 
Parker, L.D. (2011), "Twenty-one years of social and environmental accountability research: A coming of age", Accounting Forum, Vol. 35 No. 1, pp. 1-10.

Peh, K.S., Balmford, A., Bradbury, R.B., Brown, C., Butchart, S.H.M., Hughes, F.M.R., Stattersfield, A., et al. (2013), "TESSA : A toolkit for rapid assessment of ecosystem services at sites of biodiversity conservation importance", Ecosystem Services, Vol. 5, pp. 51-57.

Polasky, S., Caldarone, G., Duarte, T.K., Goldstein, J., Hannahs, N., Ricketts, T. and Tallis, H. (2011), "Putting ecosystem service models to work: conservation, management and tradeoffs", in Kareiva, P., Tallis, H., Ricketts, T.H., Daily, G.C. and Polasky, S. (Eds.), Natural Capital. Theory and Practice of Mapping Ecosystem Services, Oxford University Press, New York, pp. 249-263.

Posner, S., McKenzie, E. and Ricketts, T.H. (2016), "Policy impacts of ecosystem services knowledge", PNAS, Vol. 113 No. 7, pp. 1760-1765.

Posner, S., Verutes, G., Koh, I., Denu, D. and Ricketts, T. (2016), "Global use of ecosystem service models", Ecosystem Services, Vol. 17, pp. 131-141.

Primmer, E. and Furman, E. (2012), "Operationalising ecosystem service approaches for governance: Do measuring, mapping and valuing integrate sector-specific knowledge systems?", Ecosystem Services, Vol. 1 No. 1, pp. 85-92.

PUMA. (2010), PUMA's Environmental Profit and Loss Account for the Year Ended 31 December 2010, PUMA, available at: http://glasaaward.org/wpcontent/uploads/2014/01/EPL080212final.pdf.

Quattrone, P. (2009), “'We have never been Post-modern': On the Search of Management Accounting Theory", European Accounting Review, Vol. 18 No. 3, pp. 621-630.

Raar, J. (2014), "Biodiversity and regional authorities: a common-pool resources and accounting perspective", in Jones, M.. (Ed.), Accounting for Biodiversity, Routledge, Oxon, pp. 103-123.

Rambaud, A. and Richard, J. (2015), "The 'Triple Depreciation Line' instead of the 'Triple Bottom Line': Towards a genuine integrated reporting", Critical Perspectives on Accounting, Vol. 33. pp. 1-49.

Rametsteiner, E., Pülz, H., Johanna, A.-O. and Frederiksen, P. (2011), "Sustainability indicator development - Science or political negotiation", Ecological Indicators, Vol. 11, No. 1, pp. 61-70.

Rapport, D.J. and Hildén, M. (2013), “An evolving role for ecological indicators: From documenting ecological conditions to monitoring drivers and policy responses", Ecological Indicators, Vol. 28, pp. 10-15.

Remme, R.P., Schröter, M. and Hein, L. (2014), "Developing spatial biophysical accounting for multiple ecosystem services", Ecosystem Services, Vol. 10, pp. 6-18.

Richard, J. (2012), Comptabilité et Développement Durable, Economica, Paris. 
Rimmel, G. and Jonäll, K. (2013), "Biodiversity reporting in Sweden: corporate disclosure and preparers' views", Accounting, Auditing \& Accountability Journal, Vol. 26 No. 5, pp. 746 -778 .

Roberts, J. (1991), "The possibilities of accountability", Accounting Organizations and Society, Vol. 16 No. 4, pp. 355-368.

Roberts, J. and Scapens, R.W. (1985), "Accounting systems and systems of accountability Understanding accounting practices in their organisational contexts", Accounting Organizations and Society, Vol. 10 No. 4, pp. 443-456.

Rosenthal, A., Verutes, G., McKenzie, E., Arkema, K.K., Bhagabati, N., Bremer, L.L., Olwero, N., et al. (2014), "Process matters: a framework for conducting decision-relevant assessments of ecosystem services", International Journal of Biodiversity Science, Ecosystem Services \& Management, Vol. 11 No. 3, pp. 190-204.

Roslender, R. and Dillard, J.F. (2003), "Reflections on the interdisciplinary perspectives on accounting project”, Critical Perspectives on Accounting, Vol. 14, No. 3, pp. 325-351.

Ruckelshaus, M., McKenzie, E., Tallis, H., Guerry, A., Daily, G., Kareiva, P., Polasky, S., et al. (2015), "Notes from the field: Lessons learned from using ecosystem service approaches to inform real-world decisions", Ecological Economics, Vol. 115, pp. 11-21.

Saravanamuthu, K. and Lehman, C. (2013), "Enhancing stakeholder interaction through environmental risk accounts", Critical Perspectives on Accounting, Vol. 24 No. 6, pp. 410 437.

Schröter, M., Barton, D.N., Remme, R.P. and Hein, L. (2014), "Accounting for capacity and flow of ecosystem services: A conceptual model and a case study for Telemark, Norway", Ecological Indicators, Vol. 36, pp. 539-551.

Scoones, I. (1999), "New Ecology and the Social Sciences: What Prospects for a Fruitful Engagement?", Annual Reviw of Anthropology, Vol. 28, pp. 479-507.

Siddiqui, J. (2013), "Mainstreaming biodiversity accounting: potential implications for a developing economy", Accounting, Auditing \& Accountability Journal, Vol. 26 No. 5, pp. 779-805.

Soulé, M.E. (1985), “What is Conservation Biology ?”, BioScience, Vol. 35 No. 11, pp. $727-$ 734.

Spence, C., Husillos, J. and Correa-Ruiz, C. (2010), "Cargo cult science and the death of politics: A critical review of social and environmental accounting research", Critical Perspectives on Accounting, Vol. 21 No. 1, pp. 76-89.

Sukhdev, P. and Feger, C. (2012), "The Economics of Nature", Business Standard Books, Delhi.

Tallis, H. and Polasky, S. (2009), "Mapping and valuing ecosystem services as an approach 
for conservation and natural resources management", Annals of the New York Academy of Sciences, Vol. 1162, pp. 265-283.

Tallis, H. and Polasky, S. (2011), "Assessing multiple ecosystem services: an integrated tool for the real world", in Kareiva, P, Tallis, H., Ricketts, T.H., Daily, G.C. and Polasky, S. (Eds.), Natural Capital. Theory and Practice of Mapping Ecosystem Services, Oxford University Press, New York, pp. 34-50.

TEEB. (2010), The Economics of Ecosystems and Biodiversity Ecological and Economic Foundations, edited by Kumar, P., Earthscan, London and Washington.

TEEB. (2012a), The Economics of Ecosystems and Biodiversity in Business and Enterprise, edited by Bishop, J., Earthscan, London and New York.

TEEB. (2012b), The Economics of Ecosystems and Biodiversity in Local and Regional Policy and Management, edited by Wittmer, H. and Gundimeda, H., Earthscan, London and Washington.

Thomson, I. (2014), "Biodiversity, international conventions, government strategy and indicators: the case of the UK", in Jones, M. (Ed.), Accounting for Biodiversity, Routledge, Oxon, pp. 149-171.

Thomson, I., Dey, C. and Russell, S. (2015), "Activism, arenas and accounts in conflicts over tobacco control", Accounting, Auditing \& Accountability Journa, Vol. 28 No. 5, pp. 809-845.

Tregidga, H. (2013), "Biodiversity offsetting: problematisation of an emerging governance regime", Accounting, Auditing \& Accountability Journal, Vol. 26 No. 5, pp. 806-832.

Turner, R.K. and Daily, G.C. (2008), "The Ecosystem Services Framework and Natural Capital", Environmental Resource Economics, Vol. 39, No. 1, pp. 25-35.

Turner, R.K., Paavola, J., Cooper, P., Farber, S., Jessamy, V. and Georgiou, S. (2003), "Valuing nature : lessons learned and future research directions", Ecological Economics, Vol. 46, No. 2, pp. 493-510.

Turnhout, E., Hisschemöller, M. and Eijsackers, H. (2007), "Ecological indicators: Between the two fires of science and policy", Ecological Indicators, Vol. 7, No 3, pp. 215-228.

UN. (2014), System of Environmental-Economic Accounting 2012-Central Framework, United Nations,European Union, Food and Agriculture Organization of the United Nations, International Monetary Fund, Organisation for Economic Co-operation and Development, The World Bank, available at: http://unstats.un.org/unsd/envaccounting/seeaRev/SEEA CF Final en.pdf.

Vaissière, A., Levrel, H., Hily, C. and Le, D. (2013), "Selecting ecological indicators to compare maintenance costs related to the compensation of damaged ecosystem services", Ecological Indicators, Vol. 29 No. April 2004, pp. 255-269.

Waage, S. and Kester, C. (2015), Making the Invisible Visible: Analytical Tools for Assessing Business Impacts \& Dependencies Upon Ecosystem Services, BSR, available at: 
http://www.bsr.org/reports/BSR_Analytical_Tools_for_Ecosystem_Services_2015.pdf.

WAVES. (2014), Wealth Accounting and the Valuation of Ecosystem Service. Waves Annual Report 2014., World Bank Group, available at: www.wavespartnership.org.

Weber, J. (2011), An Experimental Framework for Ecosystem Capital Accounting in Europe, No. 13/2011, European Environment Agency, Copenhagen.

Weber, J.-L. (2007), "Implementation of land and ecosystem accounts at the European Environment Agency", Ecological Economics, Vol. 61 No. 4, pp. 695-707.

Weber, J.-L. (2014a), Ecosystem Natural Capital Accounts: A Quick Start Package, No. 77, Secretariat of the Convention on Biological Diversity, Montreal, available at: https://www.cbd.int/doc/publications/cbd-ts-77-en.pdf.

Weber, J.-L. (2014b), Experimental Ecosystems Natural Capital Accounts: Mauritius Case Study. Methodology and Premiminary Results 2000-2010, Indian Ocean Commission, Ebène, Mauritius, available at: http://www.ecosystemaccounting.net/wpcontent/uploads/2014/11/ENCA_Mauritius_IOC2014.pdf.

Young, R.P., Hudson, M.A., Terry, A.M.R., Jones, C.G., Lewis, R.E., Tatayah, V., Zuël, N., et al. (2014), "Accounting for conservation: Using the IUCN Red List Index to evaluate the impact of a conservation organization", Biological Conservation, Vol. 180, pp. 84-96.

Zhang, L., Liu, Q., Hall, N.W. and Fu, Z. (2007), “An environmental accounting framework applied to green space ecosystem planning for small towns in China as a case study", Ecological Economics, Vol. 60, No. 3, pp. 533-542.

Zhang, Y.I., Singh, S. and Bakshi, B.R. (2010a), "Accounting for Ecosystem Services in Life Cycle Assessment, Part I : A Critical Review”, Environmental Science \& Technology, Vol. 44 No. 7, pp. 2232-2242.

Zhang, Y.I., Singh, S. and Bakshi, B.R. (2010b), "Accounting for Ecosystem Services in Life Cycle Assessment, Part II : Toward an Ecologically Based LCA", Environmental Science \& Technology, Vol. 44 No. 7, pp. 2624-2631. 